NBER WORKING PAPER SERIES

\title{
PAY FOR SHORT-TERM PERFORMANCE: EXECUTIVE COMPENSATION IN SPECULATIVE MARKETS
}

\author{
Patrick Bolton \\ Jose Scheinkman \\ Wei Xiong \\ Working Paper 12107 \\ http://www.nber.org/papers/w12107
NATIONAL BUREAU OF ECONOMIC RESEARCH
1050 Massachusetts Avenue
Cambridge, MA 02138
March 2006

We would like to thank Lucian Bebchuk, Jeffrey Gordon and Bengt Holmstrom for helpful comments. Scheinkman is grateful to the National Science Foundation grant SES 0350770 for financial support. The views expressed herein are those of the author(s) and do not necessarily reflect the views of the National Bureau of Economic Research.

(C2006 by Patrick Bolton, Jose Scheinkman, and Wei Xiong. All rights reserved. Short sections of text, not to exceed two paragraphs, may be quoted without explicit permission provided that full credit, including (C) notice, is given to the source. 
Pay for Short-Term Performance: Executive Compensation in Speculative Markets

Patrick Bolton, Jose Scheinkman, and Wei Xiong

NBER Working Paper No. 12107

March 2006

JEL No. G1, G3

\begin{abstract}
We argue that the root cause behind the recent corporate scandals associated with CEO pay is the technology bubble of the latter half of the 1990s. Far from rejecting the optimal incentive contracting theory of executive compensation, the recent evidence on executive pay can be reconciled with classical agency theory once one expands the framework to allow for speculative stock markets.
\end{abstract}

\author{
Patrick Bolton \\ Columbia Business School \\ 804 Uris Hall \\ Columbia University \\ New York, NY 10027 \\ and NBER \\ pb2208@ columbia.edu
}

Jose Scheinkman

Department of Economics

Princeton University

Princeton, NJ 08544-1021

and NBER

joses@princeton.edu

Wei Xiong

Princeton University

Bendheim Center for Finance

26 Prospect Avenue

Princeton, NJ 08450

and NBER

wxiong@princeton.edu 


\title{
Pay for Short-Term Performance: Executive Compensation in Speculative Markets
}

\author{
Patrick Bolton, José Scheinkman, \& Wei Xiong*
}

\begin{abstract}
We argue that the root cause behind the recent corporate scandals associated with CEO pay is the technology bubble of the latter half of the 1990s. Far from rejecting the optimal incentive contracting theory of executive compensation, the recent evidence on executive pay can be reconciled with classical agency theory once one expands the framework to allow for speculative stock markets.
\end{abstract}

\section{INTRODUCTION}

In early September 2002 the news broke that "HealthSouth Corporation's chairman sold 94 percent of his company stock just weeks before the nation's biggest chain of rehabilitation hospitals revealed regulatory concerns that battered its stock price."1 By that date such announcements were hardly news, given that several major company failures had already been widely covered in the financial press, the high drama congressional hearings on Enron, Global Crossing, WorldCom, and Adelphia had taken place, and the Sarbanes-Oxley Act had been signed into law. But, perhaps better than any previous headlines, this announcement epitomized what most commentators found so troubling about the reality of executive compensation: CEOs were able to secure high rewards early, in spite of their companies' subsequent dismal performances. ${ }^{2}$

As Bebchuk and Fried underline in the preface to their new book, Pay without Performance,

[the] wave of corporate scandals that began in late 2001 shook confidence in the performance of public company boards and drew attention to potential flaws in their executive compensation practices. There is now recognition that many boards have employed compensation arrangements that do not serve

\footnotetext{
* We would like to thank Lucian Bebchuk, Jeffrey Gordon and Bengt Holmstrom for helpful comments. Scheinkman is grateful to the National Science Foundation grant SES 0350770 for financial support.

1. CNNMoney.com, HealthSouth Chair's Iffy Stock Sale, Sept. 6, 2002, http://money.cnn.com/2002/ 09/06/ news/ companies/ healthsouth/.

2. In the summer of 2002 The Financial Times published a survey of the 25 largest financially distressed firms since January 2001, and found that top executives in these firms walked away with a total of $\$ 3.3$ billion by selling their stock holdings early. Len Chang, Survivors Who Laughed All the Way to the Bank: Barons of Bankruptcy Part I, The FinANCial Times, July 31, 2002 at 10. These executives managed to build personal fortunes on the misfortune of their shareholders and employees. Id. The survey reveals, among other findings, that Kenneth Lay, the CEO of Enron, received total compensation of \$247 million, Jeffrey Skilling, the former CEO and President of Enron, received \$89 million, and Gary Winnick, the CEO of Global Crossing, received $\$ 512$ million in total cumulative compensation. Id.
} 
shareholders' interests. But there is still substantial disagreement about the scope and source of such problems and, not surprisingly, about how to address them. ${ }^{3}$

Their well-informed and timely book deals with two broad and related corporate governance issues: (1) the flaws in the executive compensation process, and (2) the lack of accountability and excessive insulation of corporate boards. Our article deals only with the first issue. While we share many of their concerns about the deficiencies of boards of directors, we differ in our assessment of executive compensation: whether executives are overpaid, the role of managerial power, and why executive compensation has risen so much over the last 15 years.

Bebchuk and Fried's main argument is that CEOs have essentially been able to set their own pay through captured boards and remuneration committees. One central regulatory and social constraint CEOs face, however, in setting their pay is mandatory disclosure of their remuneration and the potential "outrage" of outsiders on the announcement of egregiously inflated compensation. CEOs, therefore, try to elude outsider wrath by "camouflaging" their high pay as highly complex and hard to value incentive pay. Another form of camouflage CEOs can engage in is to grant themselves inflated pension plans, life insurance contracts, and golden parachutes.

Bebchuk and Fried argue that, upon closer inspection, what superficially looks like an optimal financial incentive contract is in reality just a sham. The "official view," which sees executive compensation contracts as optimal incentive contracts, has little basis in reality and can only be seen as a clever CEO sales pitch for their "rent extraction." As perspicacious as Bebchuk and Fried's observations may be, an obvious concern with their theory of camouflage of executive compensation is that it may not always live up to the basic Popperian test of falsifiability. Since they do not articulate precisely how to distinguish the reported forms of camouflaged compensation from forms of compensation that are consistent with optimal incentive contracting, it is not possible to determine which disclosed compensation contracts in reality might be inconsistent with their theory. ${ }^{4}$

But this is more of an academic quibble than our main critique to their theory. Rather, our main reservation is that, while they rightly point to important ways in which the reality of executive pay negotiations is far from the idealized arm's-length bargaining situation of the principal-agent paradigm, they do not provide a compelling explanation for how and why both the level of pay and the sensitivity to stock price performance have risen so much over the 1990s. They do point to a trend towards higher pay driven by the practice of benchmarking CEO compensation at or above the average pay in peer group companies. That is, they argue that the outrage constraint was gradually relaxed during the 1990s, as CEO pay was rising across the board in all companies. True, they also allude to the bull market and the growing importance of stock options, as we emphasize, but it is not clear how the rise in stock valuations fits into their managerial power theory of executive compensation. What is the mechanism that links the two phenomena? Have

3. Lucian BebchuK \& Jesse Fried, Pay without Performance ix (2004).

4. Other parts of their theory are more easily tested, however, such as their prediction that other things equal, the level of CEO compensation is rising with CEO power vis-a-vis boards and shareholders, or that hidden forms of compensation will be performance insensitive. 
rising stock prices made higher pay for CEOs more acceptable to the public at large? Or, has greater performance-based compensation induced better performance and in turn fuelled the bull market?

As others have pointed out, their explanation that CEO power has increased during the bubble years does not square well with other trends throughout the 1990s toward greater board independence, a higher proportion of externally recruited CEOs, a decrease in the average tenure of CEOs, and higher forced CEO turnover. These latter trends bring us closer to the ideal arm's-length bargaining situation, yet they have not been accompanied by pay moderation. It is entirely possible that in contrast to their theory's prediction, the strengthening of boards during the 1990s may actually have been a cause of higher CEO pay. Indeed, in a more competitive environment, with riskier and more demanding jobs, CEOs may have required better compensation, as Hermalin argues. ${ }^{5}$ While Hermalin's theory provides a consistent alternative explanation for the rise in CEO pay, we would argue that both Hermalin and Bebchuk and Fried seriously underplay the most important development over this period: the advent of the Internet and the technology bubble.

As in previous historical episodes, when a new "general purpose technology" is developed, such as the railway, the automobile, the telegraph and telephone, or the internet, uncertainty is created as to how deeply the technology will transform the economy and who will appropriate the economic gains. This uncertainty is likely to translate into differences of opinion among investors. As we will argue, these differences of opinion in turn fuel speculation in stock markets and can bring about a stock market bubble. Looking back, it may well be that historians will see the technology bubble as the major historical event of the latter half of 1990s, and in our view, this episode of speculation is also the main factor that has affected the evolution of executive pay over this period.

In our previous article, Executive Compensation and Short-Termist Behavior in Speculative Markets, we expand the classical principal-agent framework of optimal incentive contracting (the "official view," in Bebchuk and Fried's terminology) to incorporate the possibility that equilibrium stock prices do not always provide an unbiased measure of firm fundamentals. ${ }^{6}$ That is, we allow for stock valuations that may be significantly higher than fundamental value during speculative episodes driven by sharp differences of opinion among investors. In this expanded framework we determine the incentive contract that optimally trades off risksharing and CEO incentives. Our key finding is that when there are large differences of opinion, the optimal compensation contract induces a greater short-term CEO orientation and encourages actions that fuel speculation and short-term stock price performance at the expense of long-run firm fundamental value.

While remaining within the classical agency framework we are thus able to explain why it is optimal for shareholders to offer compensation contracts that allow CEOs to profit early from a speculative stock price surge even if at a later date share prices

5. Benjamin E. Hermalin, Trends in Corporate Governance, 60 J. Fin. 2351 (2005).

6. Patrick Bolton, Jose Scheinkman \& Wei Xiong, Executive Compensation and Short-Termist Behavior in Speculative Markets, (National Bureau of Econ. Research, Working Paper No. W9722, 2003), available at http://ssrn.com/abstract=410649. 
collapse. We are also able to explain why stock-based compensation rises in speculative markets. In our theory, the critical departure from the official view is not the gradual erosion of shareholders' bargaining power, as in Bebchuk and Fried's theory, but is rather a broader perspective on stock markets that allows for the possibility of speculative bubbles. We believe that the most important event that influenced executive compensation in the latter half of the 1990s was the technology bubble and not a fundamental break in the bargaining process. Thus, while we agree with Bebchuk and Fried that anything that brings the bargaining process closer to the ideal arm's-length bargaining situation is desirable, we think that by focusing on the bargaining process they are not identifying the root cause of the change in executive compensation in the last decade. The root cause lies elsewhere, in the technology bubble. ${ }^{7}$

In this Article our focus is on earnings manipulation. We also consider a somewhat simpler setting than in our previous paper, Executive Compensation and Short-Termist Behavior in Speculative Markets. ${ }^{8}$

It is well recognized that the technology bubble has induced, or has been accompanied by, a number of new trends, one of which is the growth in earnings manipulation, ranging from fairly innocuous earnings "smoothing" to outright accounting fraud. This is reflected, for example, in the enormous growth in earnings restatements during the 1990s. While there were only six restatements in 1992, and five in 1993, there were over 700 restatements during the period between 1997 and 2000.

In this Article we explain how speculative markets create incentives for such manipulation. Importantly, we highlight how earnings manipulation is not directly linked to an agency problem between the CEO and shareholders. Rather, it is primarily driven by a fundamental conflict between current and future shareholders. To emphasize this point we begin our analysis by considering incentives to manipulate earnings by a privately held firm run by a single owner-manager prior to going public. We show that even in such a firm, where there is no separation of ownership and control, and therefore no scope for any form of rent extraction by the CEO, there will be "speculative" incentives to manipulate earnings if the stock market is not fully rational. By beginning our analysis with this example we aim to emphasize an important point that has been largely overlooked in the current debate on executive compensation. Namely, that besides the usual agency conflict with the CEO, there is also a conflict among shareholders that is exacerbated in speculative markets.

7. It is worth noting that writing independent of ours, the leading proponents of the "official view," Michael Jensen and Kevin Murphy, have also singled out the technology bubble as the root cause of the perceived failures of current executive pay. Using vigorous and vivid language, Michael Jensen has written:

The recent dramatic increase in corporate scandals and value destruction is due to what I call the agency costs of overvalued equity. I believe these costs have amounted to hundreds of billions of dollars in recent years. When a firm's equity becomes substantially overvalued it sets in motion a set of organizational forces that are extremely difficult to manage, forces that almost inevitably lead to destruction of part or all of the core value of the firm.

See Michael Jensen, Agency Costs of Overvalued Equity (Eur. Corp. Governance Inst., Working Paper No. 39/2004, 2004), available at http://www.ecgi.org/wp/wp_id.php?id=59; Michael Jensen \& Kevin Murphy, Remuneration: Where We've Been, How We Got to Here, What Are the Problems, and How to Fix Them (Eur. Corp. Governance Inst., Working Paper No. 44/2004, 2004), available at http://www.papers.ssrn.com/8013/ papers.cfm?abstract_id $=480421$.

8. Bolton, Scheinkman \& Xiong, supra note 6. 
The CEO has a duty of loyalty towards current shareholders and not future shareholders. Thus, if he artificially drives up the stock price in the short run at the expense of long run value he may be acting in the interests of his current principals. Current shareholders may well choose to incentivize the CEO for short-term stock performance, even if they understand that this also creates incentives for the CEO to manipulate earnings. The reason is simply that current shareholders want the CEO to pursue their interests even if this comes at the expense of future shareholders. Importantly, this conflict between current and future shareholders can only arise in a speculative or irrational market. In the efficient market, presumed by the "official view," current value can only be increased along with future value. This assumption is why the classical agency perspective does not identify a conflict between current and future shareholders. But, as we show in our model, when some investors are sometimes (or always) overconfident or inattentive, and when stock markets are undergoing a speculative phase, then earnings manipulation that destroys long-run fundamental value will drive up short-term stock performance. ${ }^{9}$

The remainder of our Article is structured as follows: Part II discusses how speculative bubbles may arise in markets with short-sales constraints when there are large differences of opinion among investors. Part III introduces an example that shows how a basic conflict between current and future shareholders emerges in speculative markets and how this conflict gives rise to earnings manipulation. Part IV continues the analysis by expanding the example to deal with a classical agency problem and deriving implications for the optimal executive compensation contract in the presence of speculative markets. Part V discusses some of the key observed provisions in CEO compensation contracts in light of Bebchuk and Fried's managerial power theory, the official view, and our shareholder conflict theory. Finally, Part VI discusses regulatory implications and recommendations for reform of executive pay. In the Appendix we exposit a simple mathematical model that extends the discussions of Parts III and IV, and we derive the optimal compensation of executives when stock prices contain a speculative component.

\section{OverConfiDENCE, DifFERENCES OF OPINION AND STOCK MARKET BUBbleS}

The evidence that stock prices can deviate from fundamental values for prolonged periods of time is accumulating. ${ }^{10}$ That the NASDAQ run-up of the latter half of the

9. Our analysis is redolent of the commonly held view among corporate managers, forcefully articulated by Michael Lewis below, that short-term oriented shareholders played a pernicious role at the height of the technology boom:

The investor cares about short-term gains in stock prices a lot more than he does about the longterm viability of a company. Indeed, he does not seem even to notice that the two goals often conflict.

... The investor, of course, likes to think of himself as a force for honesty and transparency, but he has proved, in recent years, that he prefers a lucrative lie to an expensive truth. And he's very good at letting corporate management know it.

Michael Lewis, The Irresponsible Investor, N.Y. TIMES, June 6, 2004, § 6, (Magazine), at 68.

10. Classical asset pricing models typically assume that investors rationally project future cash flow based on public and privately processed information, and then discount the cash flow based on risk-adjusted discount rates. Thus, an investor can only earn higher average returns by bearing more systematic risks. However, over the past two decades, economists have uncovered many puzzles in stock returns that are difficult to explain 
1990s was an episode of considerable overvaluation is by now a widely shared view. ${ }^{11}$ An example that epitomizes these excessive valuations is the market valuation of Palm, the by now well-known manufacturer of personal digital assistants, which at some point during this period had higher valuations than its parent company 3 Com by as much as $\$ 23$ billion, a glaring violation of the law of one price that underlies any rational asset pricing model based on fundamental values. ${ }^{12}$ However, as much as commentators might agree that we have witnessed a major bubble, it is still far from well understood how such episodes come about and what the underlying forces are that generate and fuel such a bubble. Our favored explanation relies on three fundamental observations.

First, many investors are not fully rational and exhibit various psychological biases in their financial decisionmaking. ${ }^{13}$ Overconfidence is one of the most documented biases. Extensive studies in psychology have revealed that people are generally overconfident in their judgment. That is, they assign too much weight to their own knowledge or forecasting ability, and are found to assign overly narrow confidence intervals to their estimates of quantities they are asked to evaluate or predict. ${ }^{14}$ Overconfidence is especially relevant given the fact that investors have limited information processing abilities and can only absorb a limited amount of available information at any time. ${ }^{15}$ Consequently, some investors may put too much weight on the

based only on variations in systematic risk. For example, researchers have identified the so-called "firm size effect," "value-glamour effect," "January effect," "short-term momentum" and "long-term reversal effect." See, for example, Shleifer's literature reviews, ANDREI SHLEIFER, INEFFICIENT MARKETS: AN INTRODUCTION TO Behavioral Finance (2000), and David Hirshleifer, Investor Psychology and Asset Pricing, 56 J. Fin. 1533, 1555-63 (2001), for a summary and discussion of this evidence.

11. Many economists, including Robert Shiller, Burton Malkiel, and Michael Jensen commented on the valuation of many Internet and high-tech firms during the years 1999 and 2000 as evidence of a bubble. See Robert Shiller, IrRational Exuberance (2000); Burton G. Malkiel, The Efficient Market Hypothesis and Its Critics, 17 J. ECON. PERSP. 59, $74-76$ (2003); Michael Jensen, Agency Costs of Overvalued Equity (Eur. Corp. Governance Inst., Working Paper No. 39/2004, 2004).

12. See Owen A. Lamont \& Richard H. Thaler, Can the Market Add and Subtract? Mispricing in Tech Stock Carve-outs, 111 J. POL. ECON. 227, 230-31 (2003) (discussing the 3Com and Palm valuations and the violation of the law of one price).

13. Many psychological biases, such as "overconfidence," "representativeness," "anchoring," "limited attention," and "aversion to losses," have been invoked in the behavioral finance literature to explain a number of investor behavior patterns and stock price dynamics. See, e.g., Hirshleifer, supra note 11, at 1533-97 (2001); Nicholas Barberis \& Richard Thaler, A Survey of Behavioral Finance, in HANDBOOK OF THE ECONOMICS OF FINANCE (George Constantinides et al. eds., 2003).

14. For example, an experimental study by Alpert and Raiffa shows that $98 \%$ of confidence intervals assigned by human subjects include the true quantity only $60 \%$ of the time. See Marc Alpert \& Howard Raiffa, A Progress Report on the Training of Probability Assessors, in JUdGMENT UndER UnCERTAINTY: HeURISTICS AND BIASES 294 (Daniel Kahneman et al. eds., 1982). Another study by Fischhoff, Slovic, and Lichtenstein finds that events that people think are certain to occur actually occur only around $80 \%$ of the time, and the events that they deem impossible to occur happen approximately $20 \%$ of the time. See Baruch Fischhoff, Paul Slovic, \& Sarah Lichtenstein, Knowing with Certainty: The Appropriateness of Extreme Confidence, $3 \mathrm{~J}$. EXPERIMENTAL PSYCHOL. HuM. PERCEPTION \& PERFORMANCE, 552-64 (1977).

15. There is growing empirical evidence that investors may not incorporate all the available public information at a reasonable speed. For example, according to a case study by Huberman and Regev, the stock price of a pharmaceutical company, EntreMed, did not react to the initial news of its new cancer-curing drug until the news was re-iterated on the front page of the New York Times several months later. See Gur Huberman \& Tomer Regev, Contagious Speculation and a Cure for Cancer: A Non-Event that Made Stock Prices Soar, 56 J. Fin. 387-96 (2001). 
reported number of "clicks" on a firm's website, or on sales growth figures, as many did during the "dot-com" boom. Overconfidence prevents these investors from considering the possibility that other valuable information may have been ignored. Alternatively, as we model here, some investors may take reported earnings at face value, without looking deeper into a firm's accounts.

Second, investors' intrinsic overconfidence generates differences of opinion, since at any given time investors overweigh their own information and at the same time they underweigh others' information. Thus, at any moment in time there will be "optimists" about a firm's (or the economy's) prospects and "pessimists." These differences of opinion in turn generate speculation, where optimists buy shares from pessimists. Economists have always been puzzled by the excessive amount of trading in stock markets, as measured by what one could reasonably predict based on a rational assetpricing model. ${ }^{16}$ As is widely documented, secondary market trading was especially intensive for Internet and high-tech stocks during the Internet boom. To return to our favorite example, Palm, its stock turned over at the astonishing rate of once every week! ${ }^{17}$ In fact, researchers have found that stock valuations are positively related corresponding to their trading volume. In other words, firms with more intensive speculation are also valued higher. ${ }^{18}$ Investor overconfidence and the resulting heterogeneous beliefs provide a plausible mechanism to generate both tremendous trading volume and high stock valuations.

Third, the existence of short-sales constraints prevents the pessimists, or more rational investors, from putting a lot of sell pressure on overvalued stocks, ${ }^{19}$ so that stock

16. By examining the trading activity of a group of investors in a discount brokerage firm, Odean finds evidence that these investors trade excessively in the sense that their returns are, on average, reduced through trading. See Terrance Odean, Do Investors Trade Too Much?, 89 AM. ECON. ReV., 1279-98 (1999).

17. Internet stocks contributed $20 \%$ to the total trading volume on NASDAQ during the bubble, although their total market value was only $6 \%$ of NASDAQ. See Eli Ofek \& Matthew Richardson, Dotcom Mania: The Rise and Fall of Internet Stock Prices, 58 J. FIN. 1113-37 (2003).

18. Stocks in both NYSE and NASDAQ with higher turnover rates during the period from 1996 to 2000 also had higher prices relative to their book values. See John Cochrane, Stocks as Money: Convenience Yield and the Tech-Stock Bubble, (Nat'l Bureau of Econ. Research, Working Paper No. W8987, 2002), available at http://ssrn.com/abstract=315337.

19. The short-sales constraints arise for many different institutional reasons. First, the charters of many mutual funds explicitly restrict them from taking short positions and trading derivative securities. Roughly $70 \%$ of mutual funds explicitly state (in Form NSAR that they file with the SEC) that they are not permitted to sell short. See A. Almazan et al., Why Constrain Your Mutual Fund Manager? (Dec. 18, 2001), available at $\mathrm{http}: / /$ ssrn.com/abstract=280999. Seventy-nine percent of equity mutual funds make no use of derivatives whatsoever (either futures or options), suggesting that funds are also not finding synthetic ways to take short positions. See Jennifer Lynch Koski \& Jeffrey Pontiff, How Are Derivatives Used? Evidence from the Mutual Fund Industry, 54 J. Fin. 791, 791-816 (1999).

Second, to short-sell a stock, one has to borrow the physical shares before the selling. However, there is not a well organized central market for investors to borrow and lend stocks, creating difficulty for pessimists to short sell. Also, lenders of shares will often charge extra fees if the shares are in high demand for shorting. Short-sellers additionally face the potential risk of having to return the borrowed shares, buying back at a higher price shares that have been pushed up by manipulators who intended to squeeze short-sellers. In fact, empirical evidence shows that there had been very little short-selling of Internet and high-tech stocks during the Internet boom, and the lack of short-selling is at least partially related to short sale costs. See Gene D'Avolio, The Market for Borrowing Stock, 66 J. Fin. ECON. 271, 271-306 (2002); Christopher Geczy et al., Stocks are Special Too: An Analysis of the Equity Lending Market, 66 J. FIN. ECON. 241, 241-69. 
prices tend to reflect mainly the beliefs of the most optimistic investors at any given time. Because of short sales constraints, speculation not only takes the form of bets between optimists and pessimists at any point in time, but the expectation of future differences of opinion itself becomes an additional motive for buying a stock. Indeed, the option itself of selling to more optimistic investors in the future at a higher price has value, which will be reflected in the current stock price.

Combining these three observations, one obtains a model of stock valuations that allows for the possibility of speculation. As plausible as it sounds, this is not yet a mainstream asset-pricing model that is covered in most modern finance texts. Still, the basic idea that short sale constraints combined with differences of opinion give rise to overvalued stocks has a long ancestry in finance. John Maynard Keynes, and a few years later John Burr Williams, described the idea. ${ }^{20}$ Miller ${ }^{21}$ and Harrison and Kreps ${ }^{22}$ proposed the first models of asset pricing with differences of opinion and short sale constraints. We rely more specifically on the recent formulation of a dynamic assetpricing model in this vein by Scheinkman and Xiong ${ }^{23}$. This model establishes for the first time a pricing formula for a stock that decomposes the market value of the stock into two components: fundamental value and a speculative option value that results from the option to resell later. We adopt their terminology here and refer to this resale option value as a bubble.

Importantly, the size of this bubble is increasing in the expected future difference of opinions among investors. As we argued above, we should expect these differences to be most pronounced and persistent following a major new event, such as the arrival of a new general purpose technology. Faced with this new event, investors begin by forming very different beliefs about its likely impact on firm fundamentals. The difference in their opinions will only gradually narrow, as investors get more information and a better understanding of the effects of the new technology. This is why it is to be expected that following such events there is likely to be a bubble.

Another factor fuelling the bubble is entry by a new group of investors, who are lured into the market by reports of high stock returns. ${ }^{24}$ The technology bubble has attracted new types of investors, such as day traders and many smaller investors, who had previously stayed out of the market but have been persuaded by the talk of a "new era" and by predictions by some of the wildest optimists that the Dow-Jones "would hit 36,000."

As many observers and participants in the latest technology bubble have witnessed, an additional force that can fuel a bubble is traders' incentives to ride the bubble for a

Last, firms are usually hostile to short-sellers and sometimes even file lawsuits directly against shortsellers. See Owen Lamont, Go Down Fighting: Short Sellers vs. Firms (Yale Univ. Working Paper No. 04-20, 2003), available at http://ssrn.com/abstract=566701 (discussing the policies of firms that restrict short selling).

20. See John Keynes, The General Theory of EMPloyment InTERest And Money (1931); John BurR Williams, The Theory of InVestment VAlue (1977).

21. Edward Miller, Risk, Uncertainty and Divergence of Opinion, 32 J. Fin. 1151, 1151-68 (1977).

22. Michael Harrison \& David Kreps, Speculative Investor Behavior in a Stock Market with Heterogeneous Expectations, 92 Q. J. ECON. 323, 323-36 (1978).

23. Jose Scheinkman \& Wei Xiong, Overconfidence and Speculative Bubbles, 111 J. POL. ECON. 1183, $1188-90$ (2003).

24. Economists sometimes call this type of behavior positive feedback trading. See J.B. De Long et al., Positive Feedback Investment Strategies and Destabilizing Rational Speculation, 45 J. FIN. 375, 375-95 (1990). 
while. That is, even if they believe that a stock is overvalued, investors may choose to hold on to it instead of selling because they expect everyone else to hold on as well. ${ }^{25}$ These incentives to stay in an overvalued market are strongest for institutional investors, who always face the risk that their clients will leave them should they perform worse than a market benchmark. Indeed, some far-sighted fund managers paid dearly for their decision to get out of the technology market in anticipation of an impending crash. Although they foresaw the eventual burst of the bubble, their clients had long abandoned them and their fund had to be closed before the bubble burst. ${ }^{26}$

Interestingly, firm managers face similar pressures when they are exposed to a bubble. If all their peers and competitors engage in earnings manipulation to boost the stock price in the short term, and they do not, they may well be punished by their shareholders for underperforming in the market and may be dismissed before the information comes out that they were actually maximizing the long-run value of the firm.

\section{ACCOUNTING MANiPULATION AND THE CURRENT SHAREHOLDER-FutURE SHAREHOLDER CONFLICT}

Having explained why differences of opinion can emerge and how bubbles can arise when there are short-sales constraints and differences of opinion, we now turn to a simple example that illustrates how firms can profit from manipulating their earnings during speculative bubbles. In the Appendix we outline the underlying analytical model on which our simple numerical example is based.

In our example we divide time into three dates: $t=0,1,2$, the minimum dates required to make our point. We begin by considering the problem of a privately held, owner-managed firm seeking to go public at date $t=1$. The owner-manager of the firm reports the firm's earnings in period 1 before putting the company up for sale in the public market. In period 2, earnings are reported by whoever is then in charge of the company. The owner-manager can manipulate period 1 earnings by moving period 2 earnings forward at a cost. For example, a common practice during the height of the technology boom was to bring forward sales in time through steep discounts to be able to report higher current sales and meet earnings forecasts. But there are many other examples of earnings manipulation that fit our broad description of higher reported period 1 earnings achieved at the expense of future earnings, including delayed investments, R\&D expenditure, and replacement of obsolete equipment.

In our example the firm would produce $\$ 20$ million of profits (in present value) without manipulation in each of the two periods 1 and 2 . The firm can also report higher earnings in period 1 of $\$ 25$ or $\$ 35$ million by moving forward earnings from period 2. There is, however, a deadweight loss in this operation: under the first (smaller) inflated earnings, the firm can only generate earnings of $\$ 14.5$ million in period 2, and under the second (much larger) inflated earnings, the firm is unable to generate any further earnings in period 2 and only makes a profit of zero. ${ }^{27}$ The owner-manager's objective is to

25. See Dilip Abreu \& Markus Brunnermeier, Bubbles and Crashes, 71 ECONOMETRICA 173, 173-204 (2003) (presenting a model for synchronization of selling in a natural setting).

26. See Markus Brunnermeier \& Stefan Nagel, Hedge Funds and Technology Bubble, 59 J. Fin. 2013, 2030-31 (2004).

27. Part of the deadweight cost may be the cost of litigation, should there be a lawsuit in the event that the 
maximize the value of the firm's shares in period 1, when he wants to sell them to a new owner. Which of these three earnings reporting strategies maximizes firm value in period 1 ?

Consider first the firm's optimal earnings report when it faces an efficient stock market at date $t=1$. Our working definition of an efficient market is somewhat stronger than the usual meaning that all investors in such a market are fully rational. We shall assume that in an efficient market investors are able to determine through their financial analysis the true fundamental value of the firm. This is just a convenient simplification, which allows us to sidestep the somewhat technical discussion of how rational investors draw inferences about firm fundamentals from reported earnings. Clearly under our definition, in an efficient market investors are able to see through any form of manipulation. Since manipulation is costly this means that the market value of the firm is maximized when there is no manipulation. Although our definition of efficient markets is somewhat extreme, note that it is not far from the conception of many economics, finance and accounting scholars, who argue that changes in accounting rules, such as different ways of allocating fixed costs or goodwill and the non-expensing of stock options do not affect firm value, as rational investors are always able to correctly value compensation reported in footnotes, and more generally "see through" any calculations or aggregation reported in income statements or balance sheets. We summarize the outcome under efficient markets in our example in the table below:

Table 1: Efficient Markets

\begin{tabular}{|l|l|l|l|}
\hline Reporting Policy & Truthful & Inflated & Highly Inflated \\
\hline Reported Earnings in $\mathrm{t}=1$ & $\$ 20 \mathrm{mil}$. & $\$ 25 \mathrm{mil}$. & $\$ 35 \mathrm{mil}$. \\
\hline Realized Earnings in $\mathrm{t}=2$ & $\$ 20 \mathrm{mil}$. & $\$ 14.5 \mathrm{mil}$. & $\$ 0 \mathrm{mil}$. \\
\hline Realized Firm Value in $\mathrm{t}=1$ & $\$ 40 \mathrm{mil}$. & $\$ 39.5 \mathrm{mil}$. & $\$ 35 \mathrm{mil}$. \\
\hline
\end{tabular}

Suppose now that stock markets are no longer efficient in the way we have defined and that differences of opinion may emerge because some naïve investors actually take reported numbers at face value. Suppose in addition that investors cannot take short positions in the stock. Now, the presence of irrational investors together with the limits of arbitrage imposed by the short sales constraint can create an incentive for the firm to engage in earnings manipulation to boost the short-term stock price, even at the expense of long-run fundamental value.

Specifically, suppose that with a $10 \%$ chance a sufficient number of naïve investors would not see through the deception and would mistakenly believe that the announced profits in period 1 actually reflect the fundamental value of the firm and that the same earnings will be realized in period 2. This mistake, as we discussed in the previous part, may be due to a combination of overconfidence and inattention. Upon observing an earnings report of $\$ 25$ million in period 1, these investors are then prepared to pay a price of $\$ 50$ million for the company in period 1, and if a profit of $\$ 35$ million is announced, of $\$ 70$ million. Rational investors, who may well be the overwhelming majority, on the other hand, are not willing to buy the company at these prices. They would instead want to sell the stock short, but the best they can do is just to stay out of the market. As a

manipulation is discovered. 
result, when the firm chooses to manipulate its earnings, the stock price will be overvalued in period 1 when, with a $10 \%$ chance, a sufficient number of naïve investors appear in the market and misinterpret the firm's reported earnings. The table below summarizes the outcome under a bubble driven by the presence of naive investors:

Table 2: "Bubble” with Naive Investors

\begin{tabular}{|l|l|l|l|}
\hline Reporting Policy & Truthful & Inflated & $\begin{array}{l}\text { Highly } \\
\text { Inflated }\end{array}$ \\
\hline Reported Earnings in $\mathrm{t}=1$ & $\$ 20 \mathrm{mil}$. & $\$ 25 \mathrm{mil}$. & $\$ 35 \mathrm{mil}$. \\
\hline Realized Earnings in $\mathrm{t}=2$ & $\$ 20 \mathrm{mil}$. & $\$ 14.5 \mathrm{mil}$. & $\$ 0 \mathrm{mil}$. \\
\hline Possible Firm Value in $\mathrm{t}=1$ & $\$ 40 \mathrm{mil}$. & $\$ 50 \mathrm{mil}$. & $\$ 70 \mathrm{mil}$. \\
\hline
\end{tabular}

Although this situation only occurs with a $10 \%$ chance, it may still induce the firm to engage in earnings manipulation. Indeed, the owner-manager's objective is to maximize the expected value of the sale in period 1. If the owner-manager reports $\$ 20$ million of profits in period 1 , he would surely sell the firm for $\$ 40$ million. If he reports $\$ 25$ million, then with a 90\% chance he would sell the firm for $\$ 39.5$ million, but with a $10 \%$ chance he would sell the firm for $\$ 50$ million. Hence his expected value is:

$.9 \times \$ 39.5$ million $+.1 \times \$ 50$ million $=\$ 40.55$ million.

On the other hand, if he reports $\$ 35$ million, the expected value of his proceeds from selling the firm would be:

$.9 \times \$ 35$ million $+.1 \times \$ 70$ million $=\$ 38.5$ million.

Clearly he is better off by choosing to bring $\$ 5$ million forward even though the real present value of realized earnings is then lower. We summarize the expected outcome when the emergence of a bubble is uncertain in the table below:

Table 3: Expected Values to Owner-Manager

\begin{tabular}{|l|l|l|l|}
\hline Reporting Policy & Truthful & Inflated & Highly Inflated \\
\hline Reported Earnings in $t=1$ & $\$ 20 \mathrm{mil}$. & $\$ 25 \mathrm{mil}$. & $\$ 35 \mathrm{mil}$. \\
\hline Realized Earnings in $t=2$ & $\$ 20 \mathrm{mil}$. & $\$ 14.5 \mathrm{mil}$. & $\$ 0 \mathrm{mil}$. \\
\hline Expected Firm Value in $t=1$ & $\$ 40 \mathrm{mil}$. & $\$ 40.55 \mathrm{mil}$. & $\$ 38.5 \mathrm{mil}$. \\
\hline
\end{tabular}

It should be intuitive that the temptation to manipulate earnings increases with the probability that enough naïve investors appear. In fact if that chance was raised to $50 \%$, reporting $\$ 35$ million would lead to an expected value of the sale of $.5 \times \$ 35$ million +.5 $\times \$ 70$ million $=\$ 52.5$ million whereas reporting $\$ 25$ million would yield an expected value of the sale of $.5 \times \$ 25$ million $+.5 \times \$ 50$ million $=\$ 42.5$ million. In this case earnings manipulation would increase.

Here, manipulation is driven by a conflict between the current owner-manager, who has the short-run objective of maximizing the share price at date $t=1$, and the naïve future investors, who may buy the firm from the current owner. Several other studies in the accounting literature have also emphasized that manipulation is driven by investors' behavioral biases. ${ }^{28}$

28. See David Hirshleifer \& Siew Hong Teoh, Limited Attention, Financial Reporting and Disclosure, 36 J. ACCT. \& ECON. 337 (2003); David Hirshleifer, Seongyeon Lim \& Siew Hong Teoh, Disclosure to a 
We believe that this is an important conflict, which a narrow perspective of capital markets as fully informationally efficient markets suppresses. This conflict is exacerbated during speculative episodes, when a new set of often naïve investors enter the market and drive up stock prices. As our simple example highlights, when such a speculative episode becomes more likely, firms are encouraged to manipulate their earnings more, thus, raising stock prices further in the short term and fuelling more speculation. Conceivably, such speculative episodes may even lower the potential cost of manipulation. Indeed, if firms do not get penalized for restating their earnings, as was the case at the height of the bubble, then manipulation can be as easy as simply reporting erroneous numbers, omitting losses, etc. The firm knows that it will have to restate its earnings at a later date, but there will be little consequence to that.

Manipulation of earnings is generally associated with an agency conflict between managers and shareholders and the idea that manipulation might arise even when there is no separation of ownership and control might seem far-fetched. But, we believe that such an assumption is supported more by the intellectual habit of presuming that stock prices always reflect rational investors' valuations in informationally efficient capital markets than by facts. Indeed, there is growing evidence that not all investors are as smart as efficient market models have assumed and that firms do take advantage of these investors.

The earnings reported in firms' financial statements contain cashflows from operations and accruals. The accrual component is more transitory than the cashflow component, and is often subject to firms' discretion and therefore vulnerable to manipulation. However, a revealing study by Sloan finds evidence that investors often fail to distinguish between these two components in firms' earnings announcements. ${ }^{29}$ In other words, investors exaggerate the persistence of current earnings if the accrual component is above average, and they underestimate this persistence if it is below average. Sloan argues that a trading strategy based on buying stocks with a low accrual component and simultaneously shorting stocks with a high accrual component could produce excessive returns that cannot be explained with systematic risk. ${ }^{30}$

An important study of "reverse" leveraged buyouts (LBOS) by DeGeorges and Zeckhauser ${ }^{31}$ that predates the technology bubble finds indirect evidence of manipulation of earnings by these firms in the three years preceding their IPO. Indeed, the authors find that these firms systematically report above-average earnings prior to the IPO and belowaverage earnings in subsequent years. In a later, more general study on IPOs, Teoh, Welch and Wong use abnormal discretionary accruals as a measure of earnings manipulation and find that unusually high accruals pre-IPO predict low performance post IPO: firms in the most aggressive earnings management quartiles underperform those in

Credulous Audience: The Role of Limited Attention (Ohio State Univ., Dice Center Working Paper No. 2002-3, 2003).

29. See Richard G. Sloan, Do Stock Prices Fully Reflect Information in Accruals and Cash Flows About Future Earnings?, 71 ACCT. REV. 289 (1996).

30. Id. at 289-315.

31. Reverse leveraged buyouts are firms that had delisted in the 1980s by buying back and exchanging all traded shares for debt. Subsequently, a significant fraction of these LBOs returned to the capital markets by again going public. See Francois DeGeorges \& Richard Zeckhauser, The Reverse LBO Decision and Firm Performance: Theory and Evidence, 48 J. FIN. 1323, 1336-37 (1993). 
the least aggressive quartiles by $20 \%$ in the three years following the IPO. ${ }^{32}$ Finally, in their study of R\&D expenditure in the years prior to an IPO, Darrough and Rangan find evidence to the effect that investors attach greater informational value to earnings reports than R\&D investment, which induces these firms to manipulate earnings by suspending investment in R\&D before going public. ${ }^{33}$

In the presence of a conflict between current and future shareholders it is no longer clear what arm's-length bargaining in executive pay will achieve. The basic issue is which shareholder objectives the manager will be expected to pursue. It would be surprising if executive compensation were structured to encourage managers to mainly pursue the interests of future shareholders. Indeed, it is more likely that the shareholders who have a short-term focus on share price (e.g., large institutional investors) will have the greatest influence on the company. In addition, if the prevailing view is that capital markets are efficient and that stock prices reflect firm fundamentals then there will be no reason to focus on any other performance measure than stock price. This is perhaps the main reason why executive compensation has led to such a strong short-term orientation during the technology bubble. Finally, trading in secondary markets will result in the more optimistic and naïve investors holding the stock. It will be difficult for management to persuade these investors that the stock may be overvalued and that the firm should take a long-run view. Just as the value-oriented fund managers who decided to ride out the technology bubble could not stop their clients from leaving their fund in droves, managers of companies with over-valued stock will have a hard time persuading their investors to be patient.

\section{THE AGENCY PROBLEM}

We now turn to the analysis of the problem faced by a publicly traded company with dispersed owners and run by a CEO. How will executive compensation be structured by the board representing current shareholders, when there is both a classical agency conflict between the manager and the firm's owners and a conflict among current and future shareholders?

As in the classical agency formulation of the conflict of interest between the CEO and shareholders, we shall assume that the manager can improve firm fundamentals at a private cost. ${ }^{34}$ In addition, unlike most of the agency literature we also suppose that the CEO can manipulate earnings. ${ }^{35} \mathrm{We}$ otherwise frame the optimal contracting problem as

32. See Siew Hong Teoh et al., Earnings Management and the Long-Run Market Performance of Initial Public Offerings, 53 J. FIN. 1935, 1953-54 (1998).

33. Masako N. Darrough \& Srini Rangan, Do Insiders Manipulate Earnings When they Sell their Shares in an Initial Public Offering? (2004) (unpublished paper), available at http://ssrn.com/abstract=566885.

34. See, Michael G. Jensen \& William H. Meckling, Theory of the Firm: Managerial Behavior, Agency Costs and Ownership Structure, 3 J. FIN. ECON. 305 (1976); Bengt Holmstrom, Moral Hazard and Observability, 10 BELL J. ECON. 74 (1979); Bengt Holmstrom \& Jean Tirole, Market Liquidity and Performance Monitoring, 101 J. POL. ECON. 678 (1993).

35. An important exception to the agency literature that considers the implications for financial contracting of earnings manipulation is Jeffery Lacker \& John Weinberg, Optimal Contracts Under Costly State Falsification, 97 J. POL. ECON. 1345 1997. Their analysis, however, is substantially different from ours, as they only consider a static problem and only have rational investors. The equilibrium in their contracting problem is such that there is no manipulation, and for a wide set of parameters the manager optimally owns an equity stake 
in the classical arm's-length bargaining problem discussed in Bebchuk and Fried's book, where current shareholders, who may want to sell their shares at date $t=1$, and the CEO determine an optimal compensation contract in period 0. Our main conclusion here will be that, far from trying to discourage earnings manipulation, initial shareholders will structure the CEO incentive contract to align their objectives and the CEO's with respect to earnings manipulation.

Following Jensen and Meckling, ${ }^{36}$ we shall suppose that the CEO, as the agent of shareholders, is risk neutral but does not have sufficient wealth to buy all the shares in the company. To highlight our main point it is convenient to consider the extreme situation where, in fact, the CEO has no personal wealth at all and must be given a stock-based compensation contract to align his objective with those of shareholders. The incentive contract consists of three components: $s_{1} \geq 0$, the CEO's share of stocks that vests at date $t=1 ; s_{2} \geq 0$, the share of stocks that only vests at date $t=2$; and $d$, a fixed payment that can be positive or negative. ${ }^{37}$ Consistent with the assumption that the CEO has no personal wealth, we shall also assume that he cannot borrow more than an amount $d$.

Shareholders design the CEO's compensation to induce him to pursue two objectives: maximize firm fundamental value by exerting costly "effort," and manipulate earnings to maximize the share price at time $t=1$. It is easy to understand that the CEO can only be induced to supply hidden effort by tying his compensation to performance. It is less obvious why he cannot simply be instructed to manipulate earnings and why manipulation has to be incentivized. We suggest at least two reasons why it may be preferable for shareholders and the board of directors to provide incentives toward manipulation rather than instructing the CEO to engage in specific reporting practices. First, the board may lack precise information concerning the costs of manipulation. Second, giving incentives for manipulation instead of directly ordering the manager to manipulate earnings may protect the board from liability.

Our example here is simplified by assuming that the earnings manipulation problem can be separated from the problem of exerting effort to increase the fundamental value of the firm. Specifically, we assume that the deadweight costs of earnings manipulation are independent of the efforts made by the CEO to increase fundamental value. In reality, these two problems don't generally separate so neatly. For example, the incentives to manipulate earnings may be greater if the manager slacks off on maintaining or increasing firm fundamentals. We abstract from this complication here, as it is not critical to our main argument.

Concretely, in our example, we shall assume that to optimally align the CEO's objective with respect to the provision of effort, he should be given a total equity stake $\left(s_{1}\right.$ $+s_{2}$ ) equal to $10 \%$ of the total number of shares. Given that the effort provision and earnings manipulation problems separate as described above, the CEO's choice of effort only depends on the total number of shares he is given and not on the proportion of his equity stake that vests in period 1. In the Appendix, we illustrate how the CEO's optimal total equity stake is determined.

in the company, under which he has no incentive to misreport earnings.

36. See Jensen \& Meckling, supra note 34.

37. If $d$ is positive, this payment can be interpreted as the present value of all wage payments, sign-up fees, pension plans, etc. If $d$ is negative, it can be interpreted as a loan to purchase the equity stake $\left(s_{1}+s_{2}\right)$, either from the company directly or from a bank. 
While the CEO's incentives to supply effort are driven by his total equity stake, his decision whether to manipulate earnings only depends on the relative proportion of his shares that vest in periods 1 and 2 . To illustrate, let $f_{1}=\mathrm{s}_{1} /\left(\mathrm{s}_{1}+\mathrm{s}_{2}\right)$ denote the fraction of the CEO's shares that vest in period 1 and $f_{2}=\mathrm{s}_{2} /\left(\mathrm{s}_{1}+\mathrm{s}_{2}\right)$ the fraction that vests in period 2. Table 4 shows the expected payoff to the CEO for two different contracts under the three scenarios of earnings manipulation. In contract $L$, all the shares vest only in period 2. Given such a contract, the CEO would never choose to manipulate earnings, since the deadweight loss from manipulation would be apparent to all market participants at the moment when he is allowed to cash in his shares. In contract $S$, all the shares vest in period 1. For this contract, it is important to note that the expected payoffs to the CEO across the three choices of earnings manipulation are exactly proportional to the expected payoffs to the owner manager (Table 3). Thus, once given such a contract, the CEO will have the same preferences as the initial shareholders over the three possible choices of earnings manipulation, and will choose to move $\$ 5$ million of profits forward. Although we only allow for three possible scenarios of manipulation here, we show in the Appendix that even when more choices of manipulation are available it is preferable for initial shareholders to use contracts where all the granted shares vest in period 1 , since such contracts completely eliminate any possible agency cost related to earnings manipulation.

We should point out here that the CEO's effort choice is not affected by his decision on whether to manipulate earnings, as expected fundamental value increases by the same amount when the CEO supplies effort, independently of the extent to which earnings are manipulated. Also, the effort level preferred by shareholders is the same across the different scenarios of earnings manipulation. This is again an implication of our assumption that the deadweight costs of earnings manipulation are independent of the CEO's efforts to increase the fundamental value of the firm. If, as in our first example, in the presence of low effort, shareholders prefer that $\$ 5$ million of earnings be brought forward, they would also prefer that the same amount of earnings be brought forward when the CEO makes a higher level of effort.

Table 4: Expected Payoff to the CEO

Panel A: Firm Values

\begin{tabular}{|l|l|l|l|}
\hline Reporting Policy: & Truthful & Inflated & $\begin{array}{l}\text { Highly } \\
\text { Inflated }\end{array}$ \\
\hline Reported Earnings in $t=1$ & $\$ 20 \mathrm{mil}$. & $\$ 25 \mathrm{mil}$. & $\$ 35 \mathrm{mil}$. \\
\hline Realized Earnings in $t=2$ & $\$ 20 \mathrm{mil}$. & $\$ 14.5 \mathrm{mil}$. & $\$ 0 \mathrm{mil}$. \\
\hline Expected Firm Value in $t=1$ & $\$ 40 \mathrm{mil}$. & $\$ 40.55 \mathrm{mil}$. & $\$ 38.5 \mathrm{mil}$. \\
\hline Realized Firm Value in $t=2$ & $\$ 40 \mathrm{mil}$. & $\$ 39.5 \mathrm{mil}$. & $\$ 35 \mathrm{mil}$. \\
\hline
\end{tabular}

Panel B: Expected Payoffs to the CEO

\begin{tabular}{|l|l|l|l|}
\hline $\begin{array}{l}\text { Contract } L \\
\mathrm{f}_{1}=0 \%, \mathrm{f}_{2}=100 \%\end{array}$ & $\$ 4$ mil. & $\$ 3.95$ mil. & $\$ 3.5$ mil. \\
\hline $\begin{array}{l}\text { Contract } S \\
\mathrm{f}_{1}=100 \%, \mathrm{f}_{2}=0 \%\end{array}$ & $\$ 4$ mil. & $\$ 4.055 \mathrm{mil}$. & $\$ 3.85$ mil. \\
\hline
\end{tabular}


Thus, in our example the separation of ownership and control does not give rise to different incentives to manipulate earnings. The fact that a CEO will not invest as much as an owner-manager is a general prediction of the agency literature and is not surprising. On the other hand, the fact that incentives towards earnings manipulation are aligned is less obvious.

It is worth emphasizing the significance of this result. It means that if managers engage in earnings manipulation they are only doing what initial shareholders want them to do. Put somewhat differently, if shareholders disapprove of earnings manipulation they can easily remedy this problem by removing the financial incentives of managers towards manipulation. In our highly simplified model this can be done at no cost by prolonging the vesting period until date $t=2$. In reality, however, there is likely to be a cost, as a longer vesting period imposes an illiquidity cost on the CEO. Even so, the general point remains that CEOs are not alone to blame for earnings manipulation and short-termism. If they are incentivized to engage in such practices then shareholders also share responsibility.

The recent survey by Graham, Harvey and Rajgopal of over 400 financial executives on their decisions relating to financial reporting corroborates our general analysis in this section. ${ }^{38}$ Their survey finds that executives put great emphasis on meeting or beating short-term earnings benchmarks or forecasts. ${ }^{39}$ To this end, $80 \%$ of respondents report that they would be prepared to decrease discretionary spending on R\&D, advertising and maintenance to meet earnings targets. ${ }^{40}$ More disconcertingly, more than half the respondents state that they would be willing to burn "real" cash flows by, say, delaying new projects and capital expenditures for the sake of reporting expected accounting numbers. ${ }^{41}$ Their survey further reveals that the most important reason why managers care so much about earnings announcements is the effect on stock price. More than $80 \%$ of survey participants agree that meeting benchmarks helps maintain or increase the firm's stock price. ${ }^{42}$ Some participants even explicitly point out in interviews that there is a constant tension between short-term and long-term objectives of firms. ${ }^{43}$ In addition, $75 \%$ of respondents also agree that their inability to meet earnings targets is seen by the managerial labor market as a "managerial failure" that could potentially cost them their job. ${ }^{44}$ These survey results are clearly consistent with our theory that firm executives are spurred by speculation in stock markets to take on short-term actions like earnings manipulation and even delaying profitable real investment to boost short-term stock prices. ${ }^{45}$

38. John Graham et al., The Economic Implications of Corporate Financial Reporting (Duke Univ., Nat'1 Bureau of Econ. Research Working Paper No. 10550, 2004), available at http://ssrn.com/abstract=491627 .

39. Id. at $\mathrm{XX}$.

40. Id. at XX.

41. Id. at $\mathrm{XX}$.

42. Id. at $\mathrm{XX}$.

43. Graham et al., supra note 38 at XX.

44. Id. at XX.

45. It is worth highlighting that our theory of earnings manipulation and speculation differs in fundamental ways from the efficient market-based theories of short-termist behavior and earnings manipulation by Stein and von Thadden. See Jeremy Stein, Efficient Capital Market, Inefficient Firm: A Model of Myopic Corporate Behavior, 104 Q.J. ECON. 655 (1989); Ernst-Ludwig Von Thadden, Long-Term Contracts, ShortTerm Investment, and Monitoring, 62 REV. ECON. STUD. 557 (1995). First, according to these theories there 
While our analysis assumes that current shareholders who set the compensation contract are perfectly rational, it should be clear that this assumption is not essential. The critical assumption for our theory is that there may be differences of opinion among shareholders and that some shareholders attach too much informational value to earnings reports. Current shareholders could themselves be irrational or overconfident, and they would still want to provide CEOs with incentives to boost share price. And if the CEO sees that earnings manipulation is a simple way of raising stock price he will engage in such manipulation when his pay is tied to share price. Only rational buy-and-hold shareholders, who are aware of the consequences of earnings manipulation for long-run fundamentals, are concerned about temporary price increases at the expense of long-run value. If these shareholders are in control they would indeed structure the CEOs' incentives to put more weight on long-run value. However, in reality such shareholders are neither likely to be in charge of setting pay, nor are they likely to be overly concerned about reporting practices that have all the appearance of innocuous accounting gimmicks to believers in efficient markets.

Our analysis also assumes that the CEO has full tenure and is not replaced at date $t=$ 1. Again, this is not an essential assumption. If anything, job insecurity would enhance the CEOs' incentives to boost short-run stock performance as a way of reducing the risk of being fired.

To summarize, the analysis in this section reveals that incentives towards earnings manipulation by firm managers can be perfectly aligned with the interests of the firm's current shareholders. This means, in particular, that a well-governed firm will not necessarily crack down on earnings manipulation. Instating good governance practice may not be sufficient to eliminate such manipulation. Rather, regulatory intervention in the form of stricter auditing rules and harsher penalties for misrepresentation, as under Sarbanes-Oxley, may be required to fully address this problem. Interestingly, our simple framework highlights what the objective of regulators should be. Just as a bank regulator's role is to represent and protect the interests of small dispersed depositors, a securities regulator's role is to represent and protect future shareholders.

\section{OPTIMAL INCENTIVE CONTRACTS OR MANAGERIAL POWER?}

Having outlined our perspective of the implications for executive compensation of speculative bubbles, we now turn to a more wide-ranging analysis of the structure of CEO compensation contracts and more specifically the structure of executive stock options.

Bebchuk and Fried's contention is that several key features of existing stock-options are difficult to reconcile with an optimal incentive contracting perspective. Their preferred explanation is that these features are best understood as thinly disguised attempts to extract rents from shareholders while steering clear of the possible outrage of outsiders. The features they single out as particularly problematic are: (1) the common practice of granting options at the money; (2) the reloading of options once they vest and have been exercised; (3) the resetting of the strike price should the option turn out to be

would be no manipulation at all in the absence of an agency problem. Second, when ownership is separated from control, any form of manipulation of short-term performance is fully anticipated by shareholders in equilibrium and therefore cannot give rise to short-term stock price increases. 
widely out of the money; (4) the non-indexing of the strike price to general market movements; and (5) the early vesting of options. Besides stock options they also highlight how golden parachutes and generous pension plans may be difficult to rationalize as features that belong in optimal compensation contracts. We briefly discuss each of these features in turn and argue that contrary to Bebchuk and Fried's claims, these features are not always difficult to rationalize from an agency perspective, especially when viewed from a dynamic and multi-task agency perspective.

The general economic issues that Bebchuk and Fried are concerned with-whether observed CEO pay is fair and efficient, and whether it reflects the CEO's added value to the company - is a notoriously difficult question. A major obstacle anyone addressing this question faces is the difficulty in distinguishing between ex post pay outcomes, and compensation as viewed from an ex ante perspective. What looks like an outrageous reward ex post may be seen as perfectly reasonable from an ex ante perspective. This difficulty has been highlighted in the starkest and clearest terms in a classic study by Lazear and Rosen. 46

They make the striking observation that when agents are risk neutral, as opposed to a winner-take-all "tournament" or contest among agents, where the best performer gets a huge prize and all other agents get nothing, can be equivalent to a "piece-rate" incentive contract, where every agent is rewarded in proportion to his or her performance. ${ }^{47}$ Specifically, these contractual arrangements are equivalent in that they induce the same incentives and they provide the same ex ante expected compensation. ${ }^{48}$ However, from an ex post perspective they look dramatically different and the winner of the tournament looks like he received a reward that is way out of proportion to his contribution. ${ }^{49}$

This result should be seen mainly as a metaphor highlighting the difficulty in evaluating pay arrangements from an ex post perspective. However, it is worth pointing out that promotions in firms, and specifically promotions to the job of CEO, can be seen as a form of tournament. Thus, even if it were true that CEOs are able to extract significant rents it would not necessarily follow that this is inefficient when viewed from the perspective of the organization as a whole.

Another important result from the optimal incentive contracting literature worth highlighting here is that the structure of the optimal contract does not change with changes in the relative bargaining strengths of the parties. The CEO's relative stockbased compensation component will be the same whether his pay is negotiated at arm'slength or whether it is set by the CEO. Only the level of pay varies with the distribution of bargaining power and not the structure of pay. Thus, the critical elements of Bebchuk and Fried's theory that give rise to different predictions on the observed structure of CEO pay from the "official view" are their "outrage" constraints and "camouflage" technology. Simply observing that CEO pay is set by captured boards in itself does not yield different predictions from the "official view" on the structure of pay. It is only when the observed pay structure is clearly inefficient from an incentive contracting perspective that there are grounds to suspect that other forces are at play besides efficient incentive

46. Edward P. Lazear \& Sherwin Rosen, Rank-Order Tournaments as Optimum Labor Contracts, 89 J. POL. ECON. 841 (1981).

47. BEBCHUK \& FRIED, supra note 3.

48. Id.

49. Id. 
contracting. With these words of caution we now turn to a discussion of the five commonly observed features of executive compensation contracts listed above.

\section{A. At-The-Money Options}

Bebchuk and Fried share Warren Buffet's characterization of at-the-money options as just a "royalty for the passage of time." However, from a dynamic agency perspective it is not immediately obvious that it is optimal to offer an out-of-the-money option as the analyses of Cadenillas, Cvitanic, and Zapatero and Hall and Murphy highlight. ${ }^{50}$ In addition, it is not clear why at-the-money options should be the best way of extracting rents while circumventing the outrage constraint. Why not set options that are slightly in the money instead? It is not obvious that granting such options would immediately trigger outrage, especially if there was a minimum vesting period.

As for the notion that an at-the-money option provides a royalty for the passage of time given that the share price is expected to grow over time, this observation ignores the fact that the current share price already reflects investors' expectation of future prices. Thus, if there is a high expected growth rate in a stock this can only be reconciled with equilibrium no-arbitrage pricing if the underlying stock is very risky. The value of an atthe-money option only increases with the stock's expected growth rate because higher growth rates are associated with higher volatility.

Where Bebchuk and Fried have a point, however, is that there is evidence of poor understanding by directors and compensation committees of the true present value of the options granted to CEOs. ${ }^{51}$ Another observation they make, which is difficult to reconcile with an optimal incentive contracting perspective, is that there is very little variation across firms and over time in the strike price specified in options contracts. All options contracts seem to be at-the-money options. While this is clearly evidence against a strict incentive contracting perspective, however, it is not clear why this would be uncontrovertible proof in support of the managerial power explanation.

This practice could just as easily be explained as a form of industry benchmarking that helps CEOs make quick comparative valuations of competing compensation packages they are offered. It is also not clear how much more efficient out-of-the-money option contracts would be. Assessing the incentive effects of different strike prices is a difficult technical exercise, as the study by Cadenillas, Cvitanic and Zapatero highlights. ${ }^{52}$ Given these technical complexities it is entirely possible that offering at-themoney options is a good rule of thumb.

\section{B. Reloading Options and Early Vesting}

Another feature of executive compensation contracts that Bebchuk and Fried take issue with is the widespread practice of granting new options when the old ones have been exercised. They argue that this practice is difficult to reconcile with an optimal incentive contracting perspective. However, the reloading of options can be rationalized

50. See Abel Cadenillas et al., Leverage Decision and Manager Compensation with Choices of Effort and Volatility, 73 J. FIN. ECON. 71, $84-87$ (2003); Brian Hall \& Kevin Murphy, Stock Options for Underversified Executives, 33 J. АCCT. \& ECON. 3, 33-35 (2002).

51. See Jensen \& Murphy, supra note 7, at 37.

52. See Cadenillas et al., supra note 50, at 86 . 
as one way of implementing an optimal long-term incentive contract. Indeed, a central result in the literature on dynamic incentive contracts is that it is generally quite possible to implement an optimal long-term contract with a sequence of short-term contracts. ${ }^{53} \mathrm{In}$ other words, a sequence of options with short vesting periods and reloading may just be a simple way of implementing an optimal long-term contract. That is to say, reloading per se cannot obviously be characterized as clearly inefficient.

Bebchuk and Fried also argue that there is a more efficient way of structuring incentives, which is to limit CEO freedom to unwind stocks once they have exercised their options. From a different perspective than Bebchuk and Fried, we also conclude that regulatory intervention in the form of longer required vesting periods may be socially desirable. But from our point of view it is not clear that shareholders would impose these restrictions on their CEO if they had more input in the determination of CEO pay. First of all, there could be costs in terms of inefficient risk-sharing associated with such restrictions. ${ }^{54}$ Second, as we have highlighted in previous parts, the more long-term CEO orientation induced by longer vesting periods may well be undesirable for current shareholders.

\section{Resetting the Strike Price}

Bebchuk and Fried describe the practice of "backdoor repricing" as a way of rewarding managers for failure, but this issue is clearly more complex than they let on. Obviously, as they point out, ex ante incentives are undermined when CEOs expect the repricing, but then ex post incentives may be improved if the option ends up too far outof-the money. Thus, the backdoor repricing can be seen as a delicate way of balancing ex post and ex ante incentives. ${ }^{55}$ In addition, the repricing may be necessary to prevent the manager from quitting because his compensation going forward is no longer competitive.

\section{Non-Indexed Options}

A common criticism of executive compensation contracts is that they reward CEOs for absolute performance, but by the theory of optimal incentive contracting they should only be rewarded for their performance relative to market index, such as the S\&P 500. ${ }^{56}$ Bebchuk and Fried also emphasize this point and dismiss familiar explanations for this practice based on the favorable accounting treatment and tax incentives for non-indexed options. As their discussion of this issue highlights, there may also be economic reasons why it might not be sensible to offer indexed options. ${ }^{57}$ One reason in particular, may be that the return on managerial effort may be positively correlated with the market: good

53. See, e.g., Drew Fudenberg et al., Short-term Contracts and Long-Term Agency Relationships, 51 J. ECON. THEORY 1, 19-22 (1990) (presenting a statement and proof of this result).

54. See, e.g., Drew Fudenberg \& Jean Tirole, Moral Hazard and Renegotiation in Agency Contracts, 58 ECONOMETRICA 1279 (1990) (presenting an analysis of optimal unwinding of shares by CEOs once they have made the important investment decisions affecting long-run firm value).

55. See, e.g., Viral V. Acharya et al., On the Optimality of Resetting Executive Stock Options, 57 J. Fin. ECON. 65 (2000) (showing that when plausible constraints are imposed on the set of feasible compensation contracts and permitting the resetting of the strike price may well be in shareholders' ex ante interest).

56. See, e.g., Marianne Bertrand \& Sendhil Mullainathan, Are CEOs Rewarded for Luck? The Ones Without Principals Are, 116 Q. J. ECON. 901 (2001).

57. See BEBCHUK \& FRIED, supra note 3, at, 157. 
management may be worth more in good times than in bad times. Another reason why there may be so few indexed options is that it might be just as easy for CEOs to "construct" their own market hedge by shorting the S\&P 500.58 It is obviously debatable which of these reasons is most important. But one thing is clear, there seems to be no sound rationale for providing a tax and accounting advantage to non-indexed options.

\section{E. Expensing Options?}

A major and surprisingly controversial accounting reform that we broadly support along with Bebchuk and Fried, Jensen and Murphy and others is the expensing of stock options. While Bebchuk and Fried back this reform because expensing of stock options would result in better disclosure and greater pay moderation, we also point out that expensing would raise the cost of earnings manipulation. Once stock options are expensed it will be more difficult to report artificially high earnings by reducing the salary component of pay and raising the stock-option component. Of course, the success of this reform will rest on the availability of simple valuation methods that do not themselves open the door to more sophisticated forms of manipulation. ${ }^{59}$

\section{CONCLUSION, RECOMMENDATIONS AND REGULATORY IMPLICATIONS}

From a policy perspective, it obviously matters which explanation for the observed level and structure of CEO pay one favors. If, as is widely believed, the main problem with CEO compensation in the United States is a failure of corporate governance, then, as Bebchuk and Fried propose, a natural regulatory response is to strengthen the board of directors, the audit committee and the remuneration committee. But there has already been a substantial strengthening of board oversight over the 1990s and yet it does not seem to have resulted in any visible pay moderation.

If, as we propose, the leading explanation is that the recent CEO compensation excesses are a by-product of the technology bubble, then rather different policy implications emerge. Indeed, further strengthening of boards might not make a major difference. What would provide better protection to future shareholders, however, is to mandate limits on CEOs' ability to unwind their stock holdings. Similarly, as we stressed above, to the extent that the non-expensing of stock options is a form of earnings manipulation then mandating the expensing of executive compensation and all other employee stock options would be a step forward.

But, perhaps most importantly, if regulators misperceive the main source of the recent corporate crisis they may intervene in ways that could be even more damaging than if they did nothing. If the main reason for the corporate crisis lies with speculative markets or unrealistic shareholder beliefs, and not with excessive managerial power or hubris, then regulatory intervention that primarily aims at restraining managerial discretion could impose unnecessary costs on firms, stifle their initiative and appetite

58. See Gerald Garvey \& Todd Milbourn, Incentive Compensation when Executives Can Hedge the Market: Evidence of Relative Performance Evaluation in the Cross-section, 58 J. FIN. 1557, 1559 (2003); Li Jin, CEO Compensation, Diversification, and Incentives, 66 J. FIN. ECON. 29, 38-39 (2002).

59. See Ronnie Sircar \& Wei Xiong, A General Framework for Evaluating Incentive Options, (May 8, 2005) (unpublished paper), available at http://ssrn.com/abstract=420820 (2004) (providing a general tractable methodology for valuing executive compensation contracts). 
towards risk-taking, without adding any new protections for future shareholders against the pernicious effects of the next speculative episode.

The type of speculative behavior discussed in our model may also be relevant to the venture capital industry. The dismal performance of many internet projects financed by venture capitalists during the internet boom provides another example of firms pursuing value destructive projects in response to a speculative market. As shown in Hendershott, internet projects financed by venture capitalists in the years 1995 through 1997 (the early part of the internet boom) have resulted in significant wealth creation, with an averaged annualized long-term return on equity (measured at the end of 2000 after the collapse of internet stock-prices) of $64 \% .{ }^{60}$ On the other hand, the long-term returns from projects started in the later period of the boom have generally been more than disappointing, with an average return of $-46 \%$ for dot-coms financed in the years 1998 through $2000 .{ }^{61}$ However, venture capitalists have been able to successfully exit half of the dot-coms that were financed during 1997 and 1998 through either public offerings or direct sales at prices, on average, exceeding more than three times their initial investment.

Having stressed the limits of Bebchuk and Fried's managerial power theory and developed our own alternative explanation, it is only fitting to close our discussion by highlighting the many common threads in our analysis. Bebchuk and Fried and us are like doctors standing next to a patient, agreeing on the fact that the patient is sick, but reaching different diagnoses on the illness. Indeed, Bebchuk and Fried deserve a lot of credit for drawing our attention to the illness and ringing the alarm bell. Despite our different diagnoses, however, we broadly end up in agreement on many elements of an adequate treatment program, mainly the expensing of options, the removal of accounting and tax advantages for non-indexed options, and the lengthening of vesting periods. Where we may differ, perhaps, is with respect to corporate governance implications and the role of the board. Mainly, where Bebchuk and Fried call for greater shareholder voice, we point to the potential benefits of partially insulating boards and CEOs from the whims of the market. That is not to say that shareholders and directors should be given less power, but that directors, just as CEOs, should be encouraged to take a more longterm perspective. This might mean, for example, lengthening the terms of directors and tying their compensation to the long-term performance of the stock.

60. See Robert Hendershott, Net Value: Wealth Creation (and Destruction) During the Internet Boom, 10 J. CORP. FIN. 281, 291 (2004).

61. Id. 


\section{ApPendix: A Simple Model of ACCOUNTING Manipulation}

This appendix provides a more systematic formal analysis of earnings manipulation by firms during speculative bubbles that highlights the general principles underlying the numerical example developed in Parts III and IV.

\section{A. The Owner-Manager Case}

In our model, as in the example, time is divided into three dates, $t=0,1,2$. To begin, we consider the problem of an owner-managed firm at date $t=0$ seeking to go public at date $t=1$ and reporting earnings at dates $t=1$ and $\mathrm{t}=2$. The owner-manager can manipulate date $t=1$ earnings $\Pi_{I}$ by moving period-two earnings forward at a cost. Specifically, given any realized firm fundamental flow value $\theta$, we let the first and second period reported earnings be such that:

$$
\begin{aligned}
& J_{1}=\theta+a, \\
& , J_{2}=\theta-a-k a^{2},
\end{aligned}
$$

where $a$ denotes the cash flow moved from date 2 to date 1 , and $k a^{2}$ is the deadweight cost of moving cash flow $a$ forward. The firm's fundamental $\theta$ is not directly observable to the market, so that investors must rely on the report $J_{1}$ to infer the value of $J_{2}$ and thus determine the share value at $t=1$ :

$P_{1}=E\left[J_{2}\right]+J_{1}$

For simplicity, we shall assume that the owner-manager seeks to sell the entire firm in period 1 . In that case his objective is to maximize the share price at $t=1$ :

$\max E\left[J_{2} \mid J_{1}\right]+J_{1}$.

Consider first the firm's optimal earnings report $J_{l}$ when it faces an efficient market at date $t=1$, where investors are able through their financial analysis to determine the true value of the firm's fundamental $\theta$. Clearly, in such a market investors are able to see through any form of manipulation, so that the market value of the firm for any choice of $a \geq 0$ is given by:

$P_{1}=\theta-\mathrm{a}-k a^{2}+\theta+a=2 \theta-k a^{2}$.

In such a market, any form of manipulation will be wasteful and can only lower firm value. The firm then sets $a^{*}=0$. Suppose now that stock markets are no longer efficient and that differences of opinion emerge because with positive probability a fraction of investors actually take reported numbers at face value. Suppose in addition that investors cannot take short positions in the stock. Now, the presence of irrational investors together with the limits of arbitrage imposed by the short-sales constraint can create an incentive for the firm to engage in earnings manipulation to boost the short-term stock price, even at the expense of long-run fundamental value. More formally, suppose that when the firm manipulates first period earnings by $a$, then with probability $\lambda \in[0,1]$ a sufficient number of investors would not see through the deception and would mistakenly believe that the announced $J_{l}$ is exactly equal to the firm's fundamental $\theta$. These investors are prepared to pay a price $2 \pi=2(\theta+a)$ for the stock, following the announcement of $\pi_{l}=\theta+a$. Rational investors stay out of the market at the price $2 J_{I}=2(\theta+a)$, as they cannot take short positions by assumption. Thus, when the firm chooses to manipulate its earnings by setting $a>0$, the stock price will be overvalued at $t=1$ with probability $\lambda$, when a sufficient number of naïve investors appear in the market and misinterpret the firm's 
reported earnings. Although this situation only occurs with a possibly small probability $\lambda$ it may still induce the firm to engage in earnings manipulation. Indeed, in the market as we have described it the firm's objective is to choose $a$ to maximize:

$$
\lambda(2 \theta+2 a)+(1-\lambda)\left(2 \theta-k a^{2}\right) .
$$

The necessary and sufficient condition characterizing the optimum for this concave optimization problem then yields the solution:

$$
a^{*}=\lambda / k(1-\lambda)
$$

It is intuitive that $a^{*}$ should increase with $\lambda$, the probability that some naive investors will be fooled, and decrease with $k$, the deadweight cost parameter. Note that although the firm is able to raise the average first period stock price from $P_{l}$ to:

$$
P_{1}=2 \theta+\left[2 \lambda \mathrm{a}-(1-\lambda) k a^{2}\right],
$$

the overall long-run value of the firm is reduced by $k a^{2}$, or, substituting for the optimal value of $a$, by:

$$
\mathrm{k} \lambda^{2} /(1-\lambda)^{2}
$$

As our numerical example has already highlighted, manipulation is driven by a conflict between the current owner-manager, who has the short-run objective of maximizing the share price at date $t=1$, and the naive future investors, who may buy the firm from the current owner. As our simple model highlights, when a speculative episode raises $\lambda$, firms are encouraged to manipulate their earnings more, which raises stock prices further and fuels more speculation.

\section{B. Incorporating the Agency Problem}

Next, we introduce an agency problem into our model and consider how executive compensation will be optimally structured in our contracting problem, when there is both a classical agency conflict and a conflict between shareholders. Accordingly, we now let the manager improve firm fundamentals $\theta$ at a private $\operatorname{cost} \phi \theta^{2}$ (where $\theta>0$ ) as in the classical agency model. ${ }^{62}$ These private costs are best interpreted as unrealized "private benefits" the manager might be able to reap from the company at the expense of shareholders. In addition, unlike most of the agency literature we also let the CEO manipulate earnings. We otherwise frame the optimal contracting problem as in the classical arm's-length bargaining problem between the initial shareholders, who may want to sell their shares at date $t=1$ and the CEO. Our main conclusion here will be that, far from trying to discourage earnings manipulation, initial shareholders will structure the CEO incentive contract to align their objectives with respect to earnings manipulation and the CEO's.

Besides incurring the private cost $\phi \theta^{2}$ we shall suppose that the CEO is risk-neutral but does not have sufficient wealth to buy all shares in the company. In fact, we shall make the simplifying assumption that the CEO has no personal wealth at all and must be given a stock-based compensation contract to align his objective with those of shareholders. The incentive contract consists of three components: $s_{1} \geq 0$, the CEO's share of stocks that vests at date $t=1, \mathrm{~s}_{2} \geq 0$ the share of stocks that only vests at date $t=2$, and $d$ a fixed payment that can be positive or negative. Consistent with the assumption that the CEO has no personal wealth, we shall also assume that he cannot

62. See, e.g., J.A. Mirrlees, The Theory of Moral Hazard and Unobservable Behaviour: Part I, 66 REV. ECON. Stud. 3 (1999); Bengt Holmstrom, Moral Hazard and Observability, 10 BeLl J. ECON. 74 (1979). 
borrow more than an amount $d \geq 0$ to buy stock. Consider first the manager's incentives given an arbitrary contract $\left\{\mathrm{s}_{1}, \mathrm{~s}_{2}, d\right\}$. Under such a contract the manager's objective is to choose $(\theta, a)$ to solve:

$$
\begin{aligned}
& \max _{\{a, \theta\}} s_{1}\left\lfloor\lambda(2 \theta+2 a)+(1-\lambda)\left(2 \theta-k a^{2}\right)\right\rfloor+s_{2}\left[2 \theta-k a^{2}\right\rfloor-\phi \theta^{2} \\
= & \max _{\theta}\left[2\left(s_{1}+s_{2}\right) \theta-\phi \theta^{2}\right]+\max _{a}\left[2 \lambda s_{1} a-k(1-\lambda) s_{1} a^{2}-k s_{2} a^{2}\right]
\end{aligned}
$$

Note that in this problem the earnings manipulation problem is separable from the problem of increasing firm fundamental value. ${ }^{63}$ The necessary and sufficient conditions characterizing the optimum to this concave optimization problem yield the solutions:

$$
\begin{gathered}
\theta^{*}=\frac{s_{1}+s_{2}}{\phi} \\
\text { and } \\
a^{*}=\frac{\lambda s_{1}}{k\left[(1-\lambda) s_{1}+s_{2}\right]}
\end{gathered}
$$

It is easy to see from these formulae that incentives to increase fundamentals are only driven by the manager's total equity ownership stake $\left(s_{1}+s_{2}\right)$ and not by the precise time at which the manager's shares vest. On the other hand, as one might expect, incentives to manipulate earnings are driven by vesting. The more shares vest early (the higher is $\mathrm{s}_{1}$ ) the larger the CEO's incentives are to manipulate earnings.

One would expect that since the CEO only holds a fraction of the firm's shares, he would have reduced incentives to manipulate earnings relative to an owner-manager. However, the formulae above reveal that by lowering the fraction of shares that vest at date $t=2$ relative to those that vest at date $t=1$, it is possible for shareholders to give the CEO much larger incentives to manipulate than would be apparent from the CEO's total equity ownership stake $\left(\mathrm{s}_{1}+\mathrm{s}_{2}\right)$. We now show that it is in fact possible to perfectly align the CEO's objectives with those of shareholders with respect to the earnings manipulation dimension. Given that the CEO faces the borrowing constraint $d \geq-d$, it should be intuitively clear that when this constraint is binding this translates into an upper bound of equity ownership for the CEO, $\bar{s}<1$. We shall only derive the optimal contract for the special case where the constraint $\left(s_{1}+s_{2}\right) \leq \bar{s}$ is binding. In that case, the optimal contracting problem reduces to solving the following constrained optimization problem:

subject to:

$$
\max _{s_{1} \geq 0, s_{2} \geq 0}\left(1-s_{1}-s_{2}\right)\left[2 \theta+2 \lambda a-(1-\lambda) k a^{2}\right]
$$

$$
\theta=\frac{\bar{s}}{\phi} \text { and } a=\frac{\lambda s_{1}}{k\left(\bar{s}-\lambda s_{1}\right)}
$$

Substituting out $\theta$ and $a$ this problem reduces to:

$$
\max _{s_{1}} \frac{\lambda^{2}}{k}\left[\frac{2 s_{1}}{\left(\bar{s}-\lambda s_{1}\right)}-\frac{(1-\lambda) s_{1}^{2}}{\left(\bar{s}-\lambda s_{1}\right)^{2}}\right]
$$

63. As we have emphasized earlier, in reality these two problems do not generally separate so neatly and earnings manipulation may sometimes be a way for the manager to temporarily hide his poor performance. We abstract from this complication here, as it is not critical to our main argument. 
If we now define $x=\frac{s_{1}}{\bar{s}-\lambda s_{1}}$ and take $x$ to be the control variable then our problem simplifies further to:

$$
\max _{x} 2 x-(1-\lambda) x^{2}
$$

From this problem it is immediate that the solution for $x$ is $x^{*}=1 /(1-\lambda)$, and therefore, the solution for $\mathrm{s}_{1}$ is:

$$
s_{1}^{*}=\bar{s} .
$$

Finally, under this optimal incentive contract, the CEO is induced to choose exactly the same level of earnings manipulation that initial shareholders desire:

$$
a^{*}=\frac{\lambda}{k(1-\lambda)}
$$

In words, while the separation of ownership and control may result in too little investment in firm fundamental value $\theta$, it does not give rise to different incentives to manipulate earnings. The fact that a CEO will not invest as much as an owner-manager is a general prediction of the agency literature and is not surprising. In contrast, as we have explained in the main text, the fact that incentives towards earnings manipulation are aligned is less obvious. The most significant implication of this result, for our purposes, is that if managers are found to engage in earnings manipulation they are not acting against the interests of shareholders. On the contrary, they are only doing what initial shareholders want them to do. 